\title{
Cultivation of Student Translator Autonomy in UK Higher Education
}

\author{
Xiaoqing Fang ${ }^{1} \&$ Philip Morris ${ }^{2}$ \\ ${ }^{1}$ School of Foreign Languages, Zhejiang University of Science and Technology, Zhejiang province, China \\ ${ }^{2}$ School of Education, University of the West of Scotland, Scotland, UK \\ Correspondence: Xiaoqing, Fang, School of Foreign Languages, Zhejiang University of Science and Technology, \\ Zhejiang province, 310000 , China.
}

Received: February 28, 2021

doi: $10.5539 /$ elt.v14n5p41
Accepted: April 18, 2021

Online Published: April 20, 2021

\begin{abstract}
This study, based on two questionnaires directed to translation lecturers in UK Higher Education (HE), aims to explore the teacher awareness of learner autonomy in the UK university translation classroom, and the extent to which students of translation are encouraged to become autonomous learners. It covers six aspects of translation education, i.e., objective setting, learning strategies, resources, technology, learner reflection and assessment, and teacher's role. The results provide insights to the teachers' understanding of student choice, control and responsibility in autonomous translation learning. The findings suggest that the translation students in UK HE are offered the most choice in translation resources and technologies, and the least choice in co-deciding translation syllabi, specialized professional goal and teaching materials; they seem to share consistent control with their teachers over the whole learning process, from goal-setting, to translation task completion, group collaboration, final version and translation quality criteria decision, to self-evaluation and reflection; they are encouraged to take responsibility for their translation products, collaboration in class, for learning to translate, and learning to evaluate and reflect. Nevertheless, the importance of encouraging student self-evaluation, peer-evaluation and self reflection in UK translation education seems to be underestimated, and is recommended to be brought to the forefront of further research.
\end{abstract}

Keywords: learner autonomy, UK translation education, choice, control, responsibility

\section{Introduction}

Traditional approaches to the teaching of translation have been criticized as teacher-centered, and 'not well-suited...for learning how to learn autonomously after graduation' (Kiraly, 2000). Many translation educators in this conventional classroom are subject to 'Atlas Complex' (Colina, 2003); in other words, they take full responsibility for all that goes on in the classroom. Researchers argue, as discussed below, that student autonomy in the classroom serves as an important aid in the learning process, thus a great need for change in the translation classroom has been identified (Kiraly, 2000). To help solve the problems addressed above, this research focuses on the approaches of translator teachers, rather than the perspective on the students and their motivation; nevertheless, it is of great interest to the authors to develop an understanding of the teacher awareness of learner autonomy in the university translation classroom, and to what extent students of translation are encouraged to become autonomous learners in UK Higher Education.

Although a considerable amount of research has been conducted on learner autonomy in language teaching and learning (Little, 1991; Dickinson, 1993; Littlewood, 1999; Benson, 2011), very little has been published on learner autonomy in translation education, particularly from the teacher's perspective. To allow translation teachers' voices to be heard regarding learner autonomy, this paper discusses two questionnaires designed to explore teacher attitudes toward building a positive learning environment in the classroom in order to foster autonomous learning in UK universities. Then the findings from each questionnaire will be analyzed in order to better understand how teacher awareness of learner autonomy in today's UK HE translation classroom is reflected by the choices teachers provide to their students and how much responsibility they encourage their students to take in their own development. 


\subsection{Literature Review of Learner Autonomy in Language Teaching and Learning}

Early in the 1980s, Holec (1981) introduced the term autonomy to the study of foreign language teaching and learning, and defined it as 'the ability to take charge of one's own learning'. His definition of autonomy emphasized learner independence in the institutional context of formulating goals, selecting materials, making decisions about activities and strategies, monitoring progress and assessing outcomes-calling for learners to accept responsibility for all aspects of their learning. In Applied Linguistics, autonomy can be seen as the capacity 'for detachment, critical reflection, decision making and independent action' (Little, 1991); it can also be seen as the attitude of learners towards 'taking responsibility essentially concerning decision making about their own learning' (Dickinson, 1993). Littlewood (1999) even subdivides this term into proactive autonomy, similar to Holec's model, and reactive autonomy, which 'does not create its own directions but, once a direction has been initiated, enables learners to organize their resources autonomously in order to reach their goal' (Littlewood, 1999).

More recently, there has been a shift in focus, meaning that autonomous learning is no longer seen as merely an isolated individual process; rather, the skills required of the autonomous language learner can be greatly fostered within communities, associated with collective as well as individual management and choice (Williams \& Burden, 1997; Benson, 2001:2011). Social interactions are therefore crucial and indispensable to the progress of autonomous learning (Little, 1996; Raya \& Lamb, 2008). The view of autonomy as a social construct has increasingly emphasized interdependence (Allwright, 1990; Johnson and Johnson, 1991; Little, 2000; Benson \& Cooker, 2013; Murray, 2014), 'cooperation with others as a socially responsible person' (Dam, 1995), and 'interacting in and with the world' (Raya, Lamb, \& Vieria, 2007). This suggests that there are multiple approaches to understanding and investigating learner autonomy in language learning and teaching; this present study focuses primarily on the development of autonomy in the classroom.

One of the most active fields of research into autonomous language learning is social constructivism. From the perspective of social constructivism, as Kiraly (2000) makes clear, the Vygotskian view sees cognitive change 'primarily as the internalization of social processes and cultural knowledge', and develops the concept of the zone of proximal development (Vygotsgy, 1994), i.e. the distance between what a learner can do with help, and what a learner can do without help. In the constructivist classroom, the learners are the centre while the teacher acts as facilitator and observer, giving help when needed to active learners who are able to set feasible goals, assess their own skills and give reflective responses. Proper guidance and assistance from the teacher can gradually decrease in line with increased learning skills, leading to increased autonomous learning. Furthermore, Williams and Burden (1997) put forward the socio-constructivist model of motivation in language acquisition in terms of internal and external factors, emphasizing the contextual influences on the learners. This model helps to conceptualise the social dimension of autonomy and is adapted slightly in O'Leary's (2011) newer model of learner autonomy to show the important role of more competent peers in the learning process. These scholars have all expanded to some extent the definition and construct of language learner autonomy from social constructivist perspective. This paper also seeks to explore the role of teacher and peers in the development of autonomous learning in university classroom.

Although the pedagogy of autonomous learning seems to have been welcomed theoretically among researchers, this paper aims to assess the extent to which the theory actually informs teaching practices.

\subsection{Literature Review of Autonomous Learning in Translation Education}

Traditionally, as we have seen, translation teaching endeavors to familiarize students with specific translation techniques and introduce them to the skills required to produce a faithful text, mainly stressing strict linguistic equivalence (Kiraly, 1995). More recently Kiraly (1995) has suggested that a more practical objective of translation teaching should be translator competence, placing more emphasis on 'the complex nature of the professional translator's task and the non-linguistic skills required'. He also proposes that translation education move from teacher-centered to student-centered instruction, and teaching methods that 'foster responsibility, independence and the ability to see alternatives' be adopted (Kiraly, 1995). This is further developed in his elaboration of translator self-reliance (Kiraly, 2003), which can be interpreted as the 'end objective of a learner's progression toward autonomy': from uninitiated individuals to interactive pairs to collaborative groups in translator education.

More comprehensive research has been conducted to examine autonomy from the perspective of learner-development in translation education. For instance, creating a translation portfolio, according to Kiraly (2000), can help students make ipsative assessments - 'the learner's ability to evaluate his or her own progress and emerging expertise over the course and upon completion of the programme of studies'. This can play a 
significant role in developing students' capability for independently evaluating their own strengths and weaknesses. Similarly, O'Leary (2014) elaborates on the importance of students' e. portfolios and reflective logs, self and peer assessment included, in the development of autonomous learning in action. Portfolios and reflective logs, then, seem highly beneficial to learner autonomy and can be seen as a very useful learning tool.

Meanwhile, researchers are becoming increasingly aware of the significance of applying the emerging Information technology to the promotion of autonomous learning in translator education. Yumuk (2002) conducted a detailed research into how an internet-based academic translation programme in Turkey could inspire students to contemplate their learning and change their traditional teacher-dependent view of learning towards more autonomy; she suggests that students negotiate the curriculum goals in class, be trained to use Internet search methods, and give reflection and feedback on their translation tasks. Through this training, they gain more accurate understanding of their own weaknesses and strengths, and have more control over their translation learning. Similarly, Monzo (2003) notices that translation learner autonomy is enhanced by the use of on-line database with parallel texts in an English-Spanish legal translation course.

Souto and Turner (2000) regard autonomous learning as a synonym for self-directed learning in the field of languages, due to their common focus on independent, self-managed and responsible learning. Thus Zhong's (2008) empirical study of self-directed translation learning at the University of New South Wales may be seen as one of the first research studies into learner autonomy in translation education, promoting, as it does, a focus on the learner as individual. In the same vein, in order to train translators to take ownership of learning and to become autonomous learners, Washbourne (2014) suggests adapting Benson's (2001) six-fold model of autonomy based on resource, technology, learner, classroom, curriculum and teacher from language learning to translation learning, and considers the essential value of autonomy from this model as choice, meaning self-determination. Furthermore, he discusses intentional learning, in other words, the self-directed process of a learner toward achieving a learning goal without systematic instructions from others (Washbourne, 2014), and summarizes eight important correlated concepts for intentional learning in translator training — challenge-seeking behavior, tolerance of ambiguity, ethics, creativity, self-management, learning to learn, reflection and empowerment, of which, the latter three are of our most interest.

According to Washbourne (2014), most of the emerging literature on how translators make choices is still restricted to 'issues of risk assessment, or to textual interpretation and evaluation'. Only rarely does it focus on 'novice translator's choices about solution paths, text selection, peer assessment, or learning networks and careers'. With the focus of emerging literature in mind, the research project investigates the extent to which UK university translation teachers are aware of the importance of autonomous learning and how students are encouraged to be self-directed learners from different aspects, hoping to shed light on the promotion of optimizing translation classroom teaching and evaluation in higher education.

\subsection{Research Aims}

Our study addresses three major research questions:

1) How much choice do UK university translation teachers provide their students in the classroom to foster autonomous learning, to what degree are these choices made available? What factors influence these choices?

2) Over which aspects are translation students encouraged to have control during their learning process?

3) What corresponding responsibility are these students encouraged to take in translation classroom to be autonomous learners, and what are the relationships between choice, control and responsibility?

The questionnaires used Washbourne's concept of choice as defined above. In terms of control, Benson (1996) emphasized its central status to autonomy, and viewed it as the ability of 'collective decision-making'. Responsibility is also crucial to autonomous learning. Taking responsibility for learning requires learners' willingness to make major contribution to their own progress and consciousness of monitoring their own development (Scharle \& Szabo, 2000).

\section{Research Methods}

The study took the form of two questionnaires, each of which contained 15 questions, aiming to find out how university translation teachers in the UK understand learner autonomy in their translation classes, and to what extent they encourage students to be autonomous learners. A pilot questionnaire was distributed and suggestions were collected before the questionnaires were revised and finalized. In order to invite as much participation of interested teachers as possible, the questions were divided into two questionnaires so that each questionnaire took about 3 minutes to complete. 
Four major inputs contributed to the design of these questionnaires. Firstly, the questionnaires incorporated Kiraly's (2000) arguments that translation learner developed from uninitiated individuals to members of interactive pairs. From there they became members of collaborative groups, finally becoming empowered as self-reliant, collaborative and autonomous student learners. Secondly, Chen's (2010) elaboration of reflective methods influenced the design of questions on students' self-reflection. Thirdly, Littlewood's (1999) proactive and reactive learning and Yashima's (2014) 'autonomous dependency' on trusted others provided a thought-provoking perspective of teacher-student relation in the autonomous learning environment. Fourthly, Benson's (2001) six-fold approaches to autonomy in language learning influenced the research and generated the following six aspects of translation education survey. His approaches include: (a) curriculum-based approaches (control over classroom decisions), (b) learner-based approaches (development of autonomous learning skills), (c) resource-based approaches (independent use of learning resources), (d) technology-based approaches (independent use of learning technologies), (e) classroom-based approaches (learner control, self-assessment), and (f) teacher-based approaches (control over curriculum decisions) (Washbourne, 2014).

Accordingly, rather than asking university translation teachers in the UK the direct question 'how conscious are you of learner autonomy in your translation classroom?', the questionnaires, in a less direct way, ask questions based on six concrete aspects (following Benson, 2001) and correlate them with how learner autonomy in translation classes is encouraged in UK Higher Education:

\section{Objective setting}

To investigate who, teacher or student, has control over the setting of learners' objectives in UK tertiary translation education, and to what extent students are encouraged to make choices. Learner objectives in this context can include long-term objectives such as professional career objectives, success of the course, or decisions concerning the syllabus of a translation course, and short-term goals, such as completing a translation task or compiling a glossary.

Learning strategies in translation classroom

To explore the use of individual- and group-work in the translation classroom that the UK teachers see as effective to learners' growing interaction and collaboration, and decline in teacher-dependence.

\section{Resources}

To examine how UK university students are encouraged to find sufficient resources for their translation theorization and practice. These resources may include, but are not limited to, self-instructional materials.

Technology in translation learning

To survey the most frequently used translation technologies in university translation classes in the UK, and ask whether or how the students are encouraged to learn them. A general question on teachers' attitudes towards adopting machine translation in class is also included.

Learner reflection and assessment

To assess translation-teacher awareness of the relationships between learner reflection (translation portfolio / log / diary in particular), self-assessment / group assessment and autonomous learning.

Translation teacher's role

To analyze the degree to which university translation teachers are prepared to relinquish control of the learning environment in order to promote autonomy.

Questionnaire A mainly covers the areas of translators' learning resources, technology, and the reflection and self-assessment of translation learners; Questionnaire B is about objective setting, learning strategies for translator trainees, and translation teachers' role in the UK universities.

The questionnaires were designed on the website: www.smartsurvey.co.uk, which later brought about all the descriptive statistic data in this research paper. The links to two questionnaires were distributed, and altogether thirty-five teachers completed Questionnaire A, and sixteen completed Questionnaire B. In addition to the usual multiple choice and multiple answer questions, several crucial open-ended questions were designed in the questionnaires requesting further explanations from participants. Some especially interested and thorough respondents followed up by email to discuss in more detail with the authors after they finished the survey. All these ensured that both quantitative and qualitative data were collected.

The participants were translation teachers from academic departments in 35 universities in the UK. Most of them had over ten years of translation teaching experience in universities. Among these teachers, native English 
speakers account for the majority. All their translation courses were English related, involving foreign languages German, Spanish, Arabic, Chinese, French, Italian, Portuguese, Russian,and Czech. A few teachers claimed that they only taught translation from a foreign language to the student's native language (as suggested by one participant, for instance) to ensure accuracy, reliability and authority in target texts, while some said they offered two-way courses. $43 \%$ teachers surveyed were teaching translation for postgraduates only, $14 \%$ for undergraduates only, and another $43 \%$ were doing for both. Though there were differences in the courses the participants taught (literary translation or technical translation, general translation or specialized translation, BA course or MA course, etc.), teaching experience, and languages involved in their classes, a certain degree of consensus on pedagogical notion of building an autonomous translator training environment could still be reached through these questionnaires.

\section{Findings and Discussion}

In this section, results are presented through analysis from three aspects: choice, control and responsibility in the order of the three research questions. Questions 6,7,8,11,16, and 17 are about the choice offered by translation teachers in UK HE; Questions 13, 18, 19, 20, 26 and 27 focus on the control students have over their learning process; Questions 23-28 are mainly about the responsibility students are encouraged to take. Relationships between choice, control and responsibility in translation classroom are also discussed.

\subsection{Choice}

External choices available for translation students can emerge from translation resources, technologies, curriculum, textbooks, etc. The responses to the questionnaires reveal that translation students in the UK universities surveyed enjoy the most freedom in choosing from translation resources and technologies; however, so far as the translation syllabus, specialized professional goal and textbooks are concerned, the students are allowed to make only partial decision or limited choice under the direction of their teachers. Their respective influencing factors are also analyzed.

Table 1 and Table 2 show the choices of translation resources and technologies available for students in UK HE.

Table 1. Translation resources

\begin{tabular}{llll}
\hline Question No. & Question & Answers & Response percentage \\
\hline $\mathbf{7}$ & What do you suggest students & A. consult the teacher & $62 \%$ \\
& $\begin{array}{l}\text { do when they encounter any } \\
\text { culture-related barrier in }\end{array}$ & B. discuss with classmates & $82 \%$ \\
& translating? (multiple answers) & C. consult native speakers outside class & $88 \%$ \\
& & D. other, please specify & $56 \%$ \\
$\mathbf{8}$ & What resources do students & A. online dictionaries & $82 \%$ \\
& use most for their translation? & B. encyclopedia & $26 \%$ \\
& (multiple answers) & C. online corpus & $44 \%$ \\
& & D. parallel texts & $53 \%$ \\
& & E. all of the above & $18 \%$ \\
\hline
\end{tabular}

Questions 7 and 8 both center on translation resources. The responses to Question 8 indicate that in modern UK university translation classes, online dictionaries $(82 \%)$ are the most preferred resource for translation; online corpora $(44 \%)$ and parallel texts $(53 \%)$ also enjoy wide popularity as convenient references for completing translation tasks. It seems, then, that students are encouraged to take advantage of any pragmatic resource at UK HE according to their needs. Meanwhile, when they aim at tackling culture-related translation difficulties, more resources are involved in Question 7 such as teachers, classmates and native speakers. What is worth noting is that the teachers tend to encourage their students to seek more help from outside classroom (native speakers outside classroom 88\%) than from the traditional instructors in classroom (teachers $62 \%$ ), which might be a sign of fostering autonomous learning in resource perspective, compared to the traditional teacher-centred classroom. As for 'Other' choices to deal with translation difficulties, the participants give specified answers as follows:

(a) Read published secondary-literature that deals with such problems;

(b) Consult the client, if authentic;

(c) Consult specialists in the field if they have the contacts (e.g. doctors if they are working on a medical translation); 
(d) Reference books and Internet;

(e) Refer to academic texts on cultural transfer;

(f) Explore how other similar issues are tackled by professional translators or through online fora (forums);

The above alternatives show that students are encouraged to read extensively outside of class (literature / reference books and Internet / academic texts / forums) and interact initiatively with social resources (clients / specialists) to tackle problems in translating. It is almost certain that independent extra-curriculum translation research conducted by students can be effective strategies to enhance their autonomous learning.

Table 2. Electronic translation tool(s)

\begin{tabular}{llll}
\hline Question No. & Question & Answers & Response percentage \\
\hline 11 & Which electronic translation & A. Termbase & $18 \%$ \\
& tool(s) do your students use & B. SDL TradosWinAlign & $61 \%$ \\
& most? (multiple answers) & C. Translation Workbench & $9 \%$ \\
& & D. Google Translation Toolkit & $24 \%$ \\
& E. MemoQ & $33 \%$ \\
& F. Wordfast & $15 \%$ \\
& G. Other (please specify) & $15 \%$
\end{tabular}

Question 11 deals with the various choices of electronic translation technologies for students. Today use of technology is no longer optional but a professional necessity, and translation technologies influence all aspects of the translator's work. The tools concerning memory are particularly designed to aid translators (Biau Gil \& Pym, 2006).

The responses to Question 11 show SDL Trados WinAlign (61\%) is the most frequently used translation memory software in translation classroom, followed by MemoQ (33\%), Google Translation Toolkit (24\%), Termbase (18\%), Wordfast (15\%) and Translation Workbench (9\%). Other tools mentioned by participants include DVX, SDL Passolo and OmegaT. However, these electronic translation tools, convenient for the translation of repetitive texts or very identical texts, are not considered as applicable to the field of literary translation, which requires more creation and inspiration; nor are they required at undergraduate level, according to the remarks of two participants.

Table 3 shows how much choice students are allowed to have in setting translation objectives according to the UK teachers surveyed.

Table 3. Objective setting

\begin{tabular}{|c|c|c|c|}
\hline Question No. & Question & Answers & Response percentage \\
\hline \multirow[t]{4}{*}{6} & \multirow{4}{*}{$\begin{array}{l}\text { Do you require students to read } \\
\text { professional literature in } \\
\text { specialist fields with reasonable } \\
\text { frequency? }\end{array}$} & $\begin{array}{l}\text { A. Yes, and we suggest a few } \\
\text { specialist fields in particular. }\end{array}$ & $47 \%$ \\
\hline & & $\begin{array}{l}\text { B. Yes, and students choose the fields } \\
\text { they prefer. }\end{array}$ & $38 \%$ \\
\hline & & $\begin{array}{l}\text { C. No, because they are not sure } \\
\text { which field they will specialize in. }\end{array}$ & $15 \%$ \\
\hline & & $\begin{array}{l}\text { D. No, I don't think students are } \\
\text { particularly interested. }\end{array}$ & $0 \%$ \\
\hline \multirow[t]{2}{*}{16} & \multirow{2}{*}{$\begin{array}{l}\text { Do you negotiate joint } \\
\text { goals/syllabus for translation } \\
\text { learning with students rather than } \\
\text { simply telling them the goals? }\end{array}$} & A. yes & $44 \%$ \\
\hline & & B. no & $56 \%$ \\
\hline
\end{tabular}

Regular reading of certain professional literature is vital to translators in that particular field. As learners of translation, students are encouraged to set a long-term professional goal and read professional literature in their specialist fields with reasonable frequency in some universities. As indicated in Question 6 which is about setting a long-term professional goal for young translators, altogether $85 \%$ of teachers surveyed admit the 
important relation between reading specialist literature widely and becoming an expert translator in a certain field, and suggest a few specialist fields in particular to students or ask them to choose the fields they prefer. Only $15 \%$ of teachers choose not to require their students to read specialist literature during translation training. Not requiring such readings suggests the teachers' estimation of students' limited understanding of holistic translation discipline and uncertainty of their future career field.

The responses to Question 16 indicate that students are allowed comparatively less choice in developing course syllabi (44\%) in translation classes. The reason for providing a more fixed or rigid course syllabus might be teachers' individual choice, or their estimation of student understanding of the course. After all, 'few learners will arrive at their first class ready to take complete charge of their own learning' (Little, 2007). However, a few teachers surveyed do manage to offer a more flexible one by inviting students to negotiate the content of the course either at the beginning of a semester, in the middle or in the end as a reference for the next session of translation teaching; naturally in independent translation projects, students are allowed some autonomy in that they are given the freedom to choose topics according to their own interests.

One feature common in both professional career objectives and course syllabus setting is that students are allowed to make choices with the guidance from their teacher, or rather, teachers surveyed believe they are needed in objective setting section though students are encouraged to make partial decisions as well. This seems to highlight the teacher's function in direction-initiating section of reactive autonomy (Littlewood, 1999) in which learners do not create their own directions; a possible explanation for this might be that teachers position themselves as what Yashima (2014) defined as 'trusted others' in autonomous learning.

Table 4 suggests student choice in their teaching materials for translation theory.

Table 4. Teaching materials

\begin{tabular}{|c|c|c|c|}
\hline Question No. & Question & Answers & Response percentage \\
\hline \multirow[t]{4}{*}{17} & $\begin{array}{l}\text { Do you use textbooks for } \\
\text { translation theory? }\end{array}$ & $\begin{array}{l}\text { A. Yes. I mainly use one book: } \\
\text { (title) }\end{array}$ & $0 \%$ \\
\hline & & $\begin{array}{l}\text { B. Yes. I use different chapters } \\
\text { from different books as teaching } \\
\text { materials. }\end{array}$ & $57 \%$ \\
\hline & & $\begin{array}{l}\text { C. No. I give suggestions and let } \\
\text { students decide whether and } \\
\text { which ones to follow. }\end{array}$ & $43 \%$ \\
\hline & & $\begin{array}{l}\text { D. No. Students consult me for } \\
\text { translation theory when necessary. }\end{array}$ & $0 \%$ \\
\hline
\end{tabular}

In the responses to Question 17, no participants surveyed claim to use a designated book as a translation theory textbook, but students can avail themselves of their teachers' suggestions or teaching materials to gain some insight of current translation theory. 57\% of teachers adopt different chapters from different books as teaching materials, which seemingly deprives students of their choice in scaffolding their own translation theory structure; yet $43 \%$ of teachers allow their students to choose from what the teacher suggests. The most likely reason for giving students less choice in this aspect might be the perceived lack of comprehensive understanding in translation theories. In such a case the teacher involved can be seen as a 'trusted other' (Yashima, 2014), helping his or her students identify and clarify as they learn to construct their own translation-theory framework.

\subsection{Control}

The UK translation teachers surveyed encourage their students to take control concerning when and where to complete a translation task, their collaboration in group work, deciding their final translation version and its quality criteria, and in final assessment as well. However, the degree of student control over the above aspects seems to vary.

Table 5 shows the how much students are encouraged to have control over when and where to finish a translation task individually. 
Table 5. Control over when and where to complete a translation task

\begin{tabular}{|c|c|c|c|}
\hline Question No. & Question & Answers & Response percentage \\
\hline \multirow[t]{4}{*}{18} & \multirow{4}{*}{$\begin{array}{l}\text { When your students are } \\
\text { given individual translation } \\
\text { tasks, can they choose when } \\
\text { and where to work on them } \\
\text { within a deadline? }\end{array}$} & $\begin{array}{l}\text { A. Yes, they can choose when } \\
\text { and where to finish it at their } \\
\text { disposal. }\end{array}$ & $63 \%$ \\
\hline & & $\begin{array}{l}\text { B. They can choose when to } \\
\text { work on it, but have to work } \\
\text { in a designated classroom. }\end{array}$ & $0 \%$ \\
\hline & & $\begin{array}{l}\text { C. They can choose where to } \\
\text { work on it in a fixed time. }\end{array}$ & $31 \%$ \\
\hline & & D. No. & $6 \%$ \\
\hline
\end{tabular}

The responses to Question 18 suggest that students are believed to have the initiative in their hands in regard to deciding where to complete a translation task $(94 \%)$ and when to complete it $(63 \%)$ within a deadline. This allows students to work in their favorable time and place as long as the task is completed in time, which is identical to the authentic work conditions of a professional translator. Only $6 \%$ of teachers decide strictly when and where their students need to finish a task, which suggests that teachers tend to trust students to accomplish given tasks on time and maintain the necessary concentration to do so.

Tables 6, 7 and 8 may provide some evidence to Benson's shared control between the student and others. According to Benson (2010), some degree of shared control between the student and others always exists in any period or aspect of learning. This control can be shared with the teacher over group work, final translation version and quality criteria (see Tables 6 and 7), or with peers over students' self-evaluation (see Table 8).

Table 6. Control over group work

\begin{tabular}{llll}
\hline Question No. & Question & Answers & Response percentage \\
\hline $\mathbf{1 9}$ & $\begin{array}{l}\text { When your students are required to work } \\
\text { in a group, can they choose which group } \\
\text { to join? }\end{array}$ & B. no & $73 \%$ \\
$\mathbf{2 0}$ & $\begin{array}{l}\text { When your students are working in a } \\
\text { group, can they decide when to move to } \\
\text { another group if necessary? }\end{array}$ & B. No & $37.5 \%$ \\
\end{tabular}

The responses to Question 19 suggest that $73 \%$ of teachers surveyed believe their students can decide which group to join when required to cooperate in a translation task. Nonetheless, it appears that students enjoy less freedom in switching between groups in the middle of an activity (Question 20) than they do at the beginning when they choose group members. This may reflect the teachers' different understanding of learner autonomy. $37.5 \%$ of teachers stress the sufficient respect and choice for students in classroom activities (in the case that students justify their move), while the other $62.5 \%$ deem it important to keep group stability. The result suggests that both the teacher and students share their control over group work during translation classroom activities. The following remarks from participants show why most teachers choose to say no to students' request of group switch:

(a) They need to learn that they cannot walk away from responsibilities at will;

(b) This is not a reality in market; they have to learn how to work with all types of people;

(c) It is hard to manage and follow up the groups and their work.

Thus it can be seen the teachers' emphasis on students' individual responsibility and complexity of group work administration are the two major considerations to group dynamics. 
Table 7. Control over final translation version and quality criteria

\begin{tabular}{llll}
\hline Question No. & Question & Answers & Response percentage \\
\hline $\mathbf{1 3}$ & Who decide(s) the final version of a translation? & A. teacher & $6 \%$ \\
& & B. students & $16 \%$ \\
& & C. both & $74 \%$ \\
$\mathbf{2 6}$ & & D. model & $4 \%$ \\
& Do you discuss translation assessment criteria in & A. yes & $87 \%$ \\
& detail with students? & B. no & $13 \%$ \\
\hline
\end{tabular}

According to the responses to Questions 13 and 26, an overwhelming majority of participants believe both teachers and students share the control over how to finalize a translation version $(74 \%)$ and how to evaluate it (87\%). Translation students in UK HE seem to be encouraged to take a high level of participation in the decision and evaluation of their translation products. This also shows most translation teachers surveyed see their role as a coordinator and a partner, rather than the sole authority in translation product determination and evaluation.

Table 8. Control over students's self-evaluation

\begin{tabular}{|c|c|c|c|}
\hline Question No. & Question & Answers & Response percentage \\
\hline \multirow[t]{5}{*}{27} & \multirow{5}{*}{$\begin{array}{l}\text { Does the final assessment } \\
\text { include } \\
\text { self-evaluation or groudents } \\
\text { members' evaluation? }\end{array}$} & A. Yes, students' self-evaluation. & $13 \%$ \\
\hline & & B. Yes, group members' & $0 \%$ \\
\hline & & evaluation. & \\
\hline & & C. Yes, both. & $20 \%$ \\
\hline & & D. No. & $67 \%$ \\
\hline
\end{tabular}

Table 8 shows the least control students take is in the evaluation section, which is traditionally regarded as completely the teacher's job. $67 \%$ of teachers in UK universities surveyed still deem the final assessment as their own duty, which can probably be explained by the gap between some students' self-evaluation (or evaluation from peers) and their performance in the teachers' eyes. $33 \%$ of teachers allow students to share limited control over student evaluation with their teachers, and $20 \%$ accept the shared control from students' peers in the same aspect. Although the ability of evaluating what has been acquired is expected to be one of the learning management tasks for autonomous learners (Holec, 1981), its credibility and the controllability of including students' self evaluation as a part of final assessment seem to need further justification.

\subsection{Responsibility for Students}

The responsibility for translation students in the UK universities surveyed can be summarized in four aspects:

Responsibility for their translation products

Responsibility for collaboration

Responsibility for learning to translate

Responsibility for learning to evaluate/reflect

Table 9 shows the responsibility translation students are encouraged to take for their translation products in UK HE.

Table 9. Responsibility for translation products

\begin{tabular}{llll}
\hline Question No. & Question & Answers & Response percentage \\
\hline $\mathbf{1 3}$ & Who decide(s) the final version of a & A. teacher & $6 \%$ \\
& translation? & B. students & $16 \%$ \\
& & C. both & $74 \%$ \\
& & D. model & $4 \%$ \\
$\mathbf{2 6}$ & $\begin{array}{l}\text { Do you discuss translation assessment } \\
\text { criteria in detail with students? }\end{array}$ & A. yes & $87 \%$ \\
& & B. no & $13 \%$ \\
\hline
\end{tabular}


The responses to Questions 13 and 26 indicate translation students in UK HE are encouraged to take the major responsibility for the quality of their translation end products, though the responsibility for final translation version and quality criteria is shared with their teachers and classmates. This shows that translation teachers surveyed seem to be aware that autonomous learning only happens when learners realize that success of learning depends as much on themselves as on the teacher, and share the responsibility for the outcome (Scharle\& Szabo, 2000).

Table 10 suggests the responsibility that UK HE translation students are encouraged to take for collaboration.

Table 10. Responsibility for collaboration

\begin{tabular}{|c|c|c|c|}
\hline Question No. & Question & Answers & Response percentage \\
\hline \multirow[t]{2}{*}{20} & \multirow{2}{*}{$\begin{array}{l}\text { When your students are } \\
\text { working in a group, can they } \\
\text { decide when to move to } \\
\text { another group if necessary? }\end{array}$} & A. Yes. & $37.5 \%$ \\
\hline & & B. No & $62.5 \%$ \\
\hline \multirow[t]{4}{*}{23} & \multirow{4}{*}{$\begin{array}{l}\text { Do you think it important to } \\
\text { organize translation work } \\
\text { groups in class to enhance } \\
\text { students' teamwork and } \\
\text { leadership skills? }\end{array}$} & $\begin{array}{l}\text { A. Yes. Both skills are important } \\
\text { for translators. }\end{array}$ & $60 \%$ \\
\hline & & $\begin{array}{l}\text { B. Teamwork skills are important } \\
\text { for translators while leadership } \\
\text { skills are not so necessary. }\end{array}$ & $20 \%$ \\
\hline & & $\begin{array}{l}\text { C. Leadership skills are more } \\
\text { important than teamwork skills for } \\
\text { translators. }\end{array}$ & $0 \%$ \\
\hline & & D. No. & $20 \%$ \\
\hline
\end{tabular}

According to Scharle \& Szabo (2000), responsible learners are prepared to cooperate with the teacher and classmates in a learning group. And the value of collaborative group work in learning cannot be overemphasized in that peers and the teacher working collaboratively help the individual internalizing process of meanings (Kiraly, 2000). The responses to Questions 20 and 23 seem to indicate that collaboration has been widely implemented in translation education in the universities surveyed, and students are strongly encouraged to be responsible for their group members in collaboration.

In $62.5 \%$ of teachers' classes (Question 20) students' consistency in adhering to their group can possibly force them to cope with their interpersonal relation issue and to be responsible to their team members.

Four fifths (Question 23) of translation teachers surveyed attach importance to group work in their classes to enhance both teamwork and leadership skills. These teachers seem to have readily let go of the conventional notion that the instructor must maintain complete control of class organization by themselves; rather, they empower students to undertake responsibility for their own learning while interacting with their peers. This wide acknowledgement of the importance of collaboration in translation education seems to support the argument that teachers recognize its significant role in the process of 'learning how to learn' (Kiraly, 2000), a lifelong autonomous learning skill that will benefit students even after they leave their universities. Moreover, it is interesting to note that more teachers tend to stress teamwork than leadership skill, reflecting a more translator-oriented teaching target than translation manager-oriented target in today's translation education. This puts emphasis on translation students' duty as a cooperator more than an organizer while working together on a translation task.

Table 11 makes it clear what responsibility translation teachers surveyed expect their students to take for learning to translate. 
Table 11. Responsibility for learning to translate

\begin{tabular}{|c|c|c|c|}
\hline Question No. & Question & Answers & Response percentage \\
\hline \multirow[t]{4}{*}{6} & \multirow{4}{*}{$\begin{array}{l}\text { Do you require students to } \\
\text { read professional literature } \\
\text { in specialist fields with } \\
\text { reasonable frequency? }\end{array}$} & $\begin{array}{l}\text { A. Yes, and we suggest a few } \\
\text { specialist fields in particular. }\end{array}$ & $47 \%$ \\
\hline & & $\begin{array}{l}\text { B. Yes, and students choose the } \\
\text { fields they prefer. }\end{array}$ & $38 \%$ \\
\hline & & $\begin{array}{l}\text { C. No, because they are not sure } \\
\text { which field they will specialize in. }\end{array}$ & $15 \%$ \\
\hline & & $\begin{array}{l}\text { D. No, I don't think students are } \\
\text { particularly interested. }\end{array}$ & $0 \%$ \\
\hline \multirow[t]{4}{*}{7} & \multirow{4}{*}{$\begin{array}{l}\text { What do you suggest } \\
\text { students do when they } \\
\text { encounter } \\
\text { culture-related barrier in } \\
\text { translating? } \\
\text { answers) }\end{array}$} & A. consult the teacher & $62 \%$ \\
\hline & & B. discuss with classmates & $82 \%$ \\
\hline & & $\begin{array}{l}\text { C. consult native speakers outside } \\
\text { class }\end{array}$ & $88 \%$ \\
\hline & & D. other, please specify & $56 \%$ \\
\hline \multirow[t]{3}{*}{9} & \multirow{3}{*}{$\begin{array}{l}\text { Do you require your } \\
\text { students to learn new } \\
\text { translation technologies by } \\
\text { themselves? }\end{array}$} & A. Yes, individually & $3 \%$ \\
\hline & & B. Yes, in groups. & $23 \%$ \\
\hline & & C. No. & $74 \%$ \\
\hline \multirow[t]{3}{*}{24} & \multirow{3}{*}{$\begin{array}{l}\text { Do you ask students to } \\
\text { discuss / revise the } \\
\text { translation work of others? }\end{array}$} & A. always & $13 \%$ \\
\hline & & B. sometimes & $87 \%$ \\
\hline & & C. never & $0 \%$ \\
\hline
\end{tabular}

The responses to Questions 6, 7,9 and 24 show that university translation students are encouraged to familiarize themselves with the learning process of translating. This process starts with creating a clear professional goal with / without the help of their instructors, and includes finding solutions to difficulties during their translation autonomously, learning new translation technologies on their own, and improving their translation by revision in most cases. Nevertheless, the importance of learning more effective and sophisticated translation technology by students themselves seems to be underestimated (74\% adverse option in Question 9). As Computer-Aided Translation software speeds up the translation process when dealing with the translation of repetitive or identical texts, new technology plays a vital role for translators in the present era (Biau Gil and Pym, 2006). Meanwhile, since it is almost impossible for students to get familiar and keep pace with the upgrading and renewal of translation technologies given the limited time they spend in translation classes, the necessity of students' autonomous learning of translation technologies outside of class should probably be brought to the forefront.

Tables 12 and 13 indicate the responsibility students are encouraged to take for learning to evaluate their own progress and to reflect in translation in UK universities surveyed.

Table 12. Responsibility for learning to evaluate

\begin{tabular}{llll}
\hline Question No. & Question & Answers & Response percentage \\
\hline $\mathbf{2 7}$ & $\begin{array}{l}\text { Does the final assessment include } \\
\text { students' }\end{array}$ & A. Yes, students' self-evaluation. & $13 \%$ \\
members' evaluation? & B. Yes, group members' evaluation. & $0 \%$ \\
& & C. Yes, both. & $20 \%$ \\
$\mathbf{2 8}$ & D. No. & $67 \%$ \\
& $\begin{array}{l}\text { Are students encouraged to learn to A. yes } \\
\text { assess their own preparedness to }\end{array}$ & B. no & $75 \%$ \\
accept professional translation jobs?
\end{tabular}

According to Table 12, the significance of students' self-assessment and mutual assessment with peer learners does not seem to receive its due attention although self-assessment is regarded as one of the 'metaskills' in learning to learn in translation education (Washbourne, 2014). Only 33\% of teachers surveyed include students' self-evaluation as a part of their final assessment, and a mere $20 \%$ include group members' evaluations. 
Comments to Question 27 from participants reveal the reasons: it is too complicated to include student self-assessment or mutual assessment in the final, and the final assessment is usually individual and timed. However, it is worth noting that 75\% (Question 28) of teachers encourage their students to learn to assess their own preparedness to accept professional translation jobs. This seems to suggest that although the majority of translation teachers find it difficult to share a certain degree of control with students over their final assessment, the teachers bear in mind the importance of empowering their students to be responsible for learning to assess their own progress. Furthermore, as indicated from the replies to the open-ended question 'how do you help them assess their preparedness', a few teachers manage to assist students' preparedness assessment for professional work by providing flexible alternatives such as evaluation questionnaires, articles on professional translators' experience, retired certification exams, or another Translation Work Experience module. These are all very effective methods to help them learn how to manage deadlines, numbers of words translated per day, electronic translation tools, etc.

Table 13. Responsibility for learning to reflect

\begin{tabular}{llll}
\hline Question No. & Question & Answers & Response percentage \\
\hline $\mathbf{2 5}$ & Do you require your students to keep & A. yes & $13 \%$ \\
& a translation diary or journal? & B. no & $87 \%$
\end{tabular}

One of the important strategies conducive to translation students' autonomous and reflective learning is using translation diary or journal (Chen, 2010). Translation diaries by students can help them record/assess their own translation process, identify problems, sort out translation strategies, sum up useful resources, build powerful glossaries, and find out their own weaknesses and strengths. It is equally important for translation teachers to use the results of students' translation diaries as an ipsative assessment, and to design tasks that target to improve students' performance. However, this responsibility for learning to reflect fails to call enough attention from university translation teachers surveyed in the UK. Only $13 \%$ of the teachers require their students to keep a translation diary or journal, but then again, some teachers recommend, rather than require, students to do so. These percentages suggest that although a substantial number of teachers might be aware of the significance of translation diaries as a powerful tool in the learning process, they are very unlikely to require that the students keep diaries.

\subsection{Relationship between Choice, Control and Responsibility}

These questionnaires also testify to the high relevance between students' choice, control and responsibility in translation education. The findings here show that the more choices are provided by the teacher, or the more control students share, the more responsibility students are encouraged to undertake.

To better demonstrate the contrastive differences between filtered groups, bar charts will be employed to analyze the correlation between choice, control and responsibility in translation learning.

Bar Chart 1 suggests the interrelation between student choice of machine translation (MT) and the responsibility of learning translation technologies (TT).

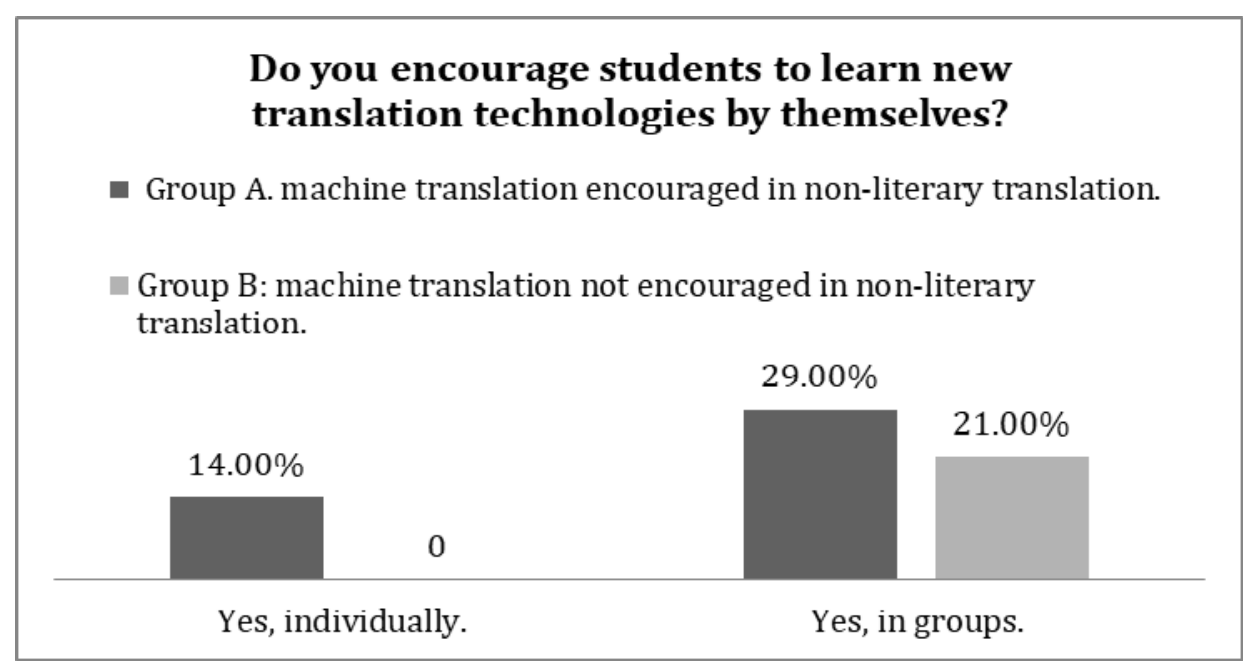

Bar Chart 1. Choice of MT \& responsibility of learning TT 
In Bar Chart 1, Group A, in which the teachers encourage students to adopt machine translation of non-literary texts before post-editing the text, is compared to Group B, in which the teachers do not encourage their students to do so. Altogether $43 \%$ of translation teachers from Group A show their preference in encouraging students' autonomous learning of translation technologies, either individually or in groups, compared to only $21 \%$ from their counterparts. This suggests that translators' confidence in machine translation correlates with their familiarity with translation technologies. Accordingly, when translation students are given more choice in practice by adopting machine translation, they will be required to take more responsibility in acquainting themselves with new translation technologies.

Another finding from Bar Chart 1 is that whether or not the teacher encourages machine translation in non-literary translation tasks, those surveyed seem to embrace the idea of learning translation technologies in groups, rather than by individuals. This is clearly supported by the gap ( $29 \%$ to $14 \%, 21 \%$ to 0 ) between group learning and individual learning of TT from two groups, which also supplements the teachers' unanimous awareness of students' responsibility for collaboration.

Bar Chart 2 shows the close interrelation between shared control over syllabus, final version, translation criteria and student responsibility for learning to evaluate.

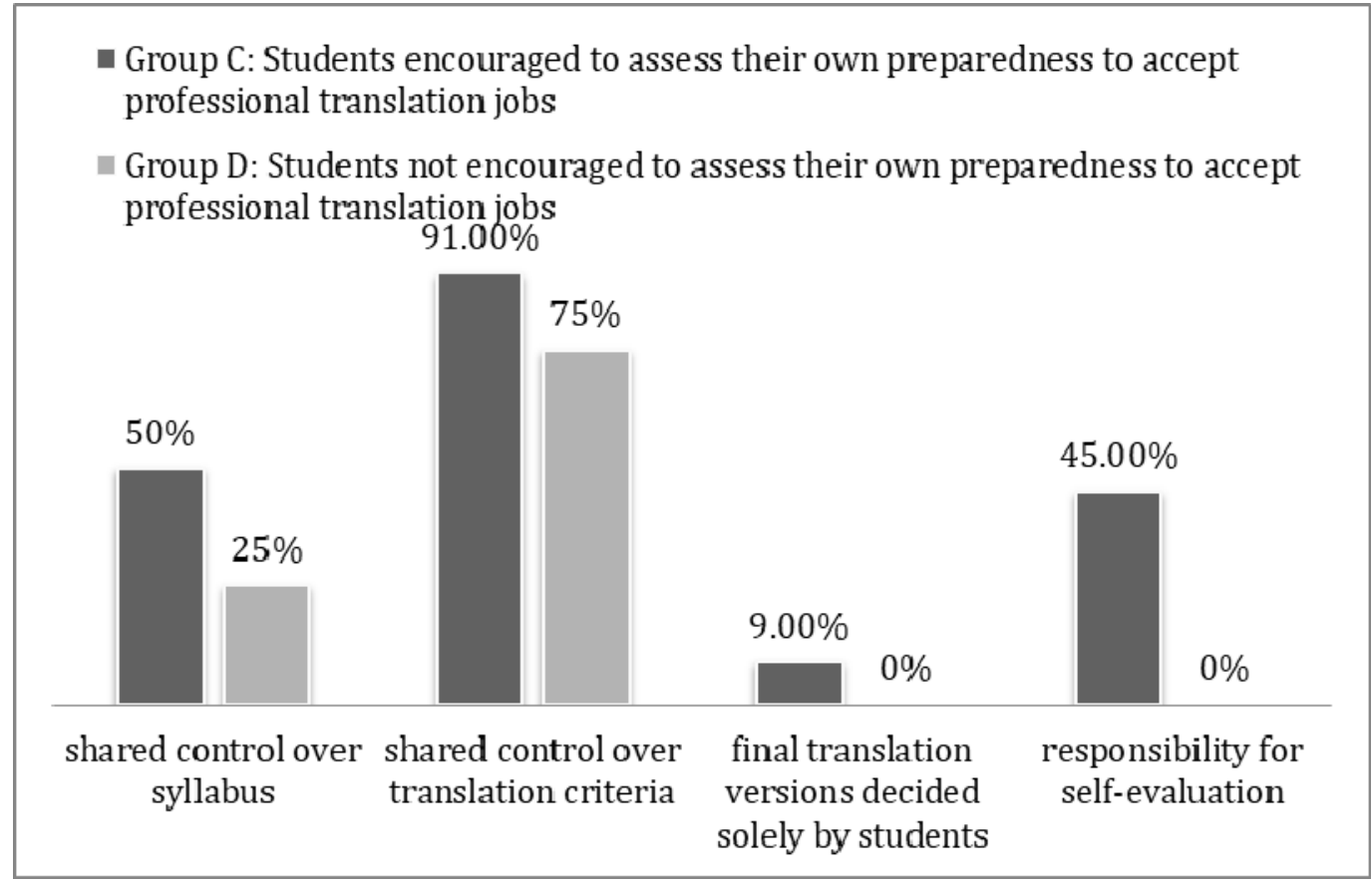

Bar Chart 2. Control \& responsibility

In Bar Chart 2, we compare Group C and Group D, and find that four aspects in translation education stand above the others in correlation with students' self-assessment of their preparedness to accept professional translation jobs. This indicates that the teachers emphasizing student self-evaluation tend also to share control with their students over syllabus decisions, translation criteria, and final version decisions. In other words, when translation students in UK HE are allowed to have more control in syllabus and translation criteria, even enjoy the sole decision on final versions, they may well be expected to undertake more responsibility for how to evaluate their own progress in translation. Thus it can be seen that student control can be closely interweaved with students' accepting responsibility in translation education. 


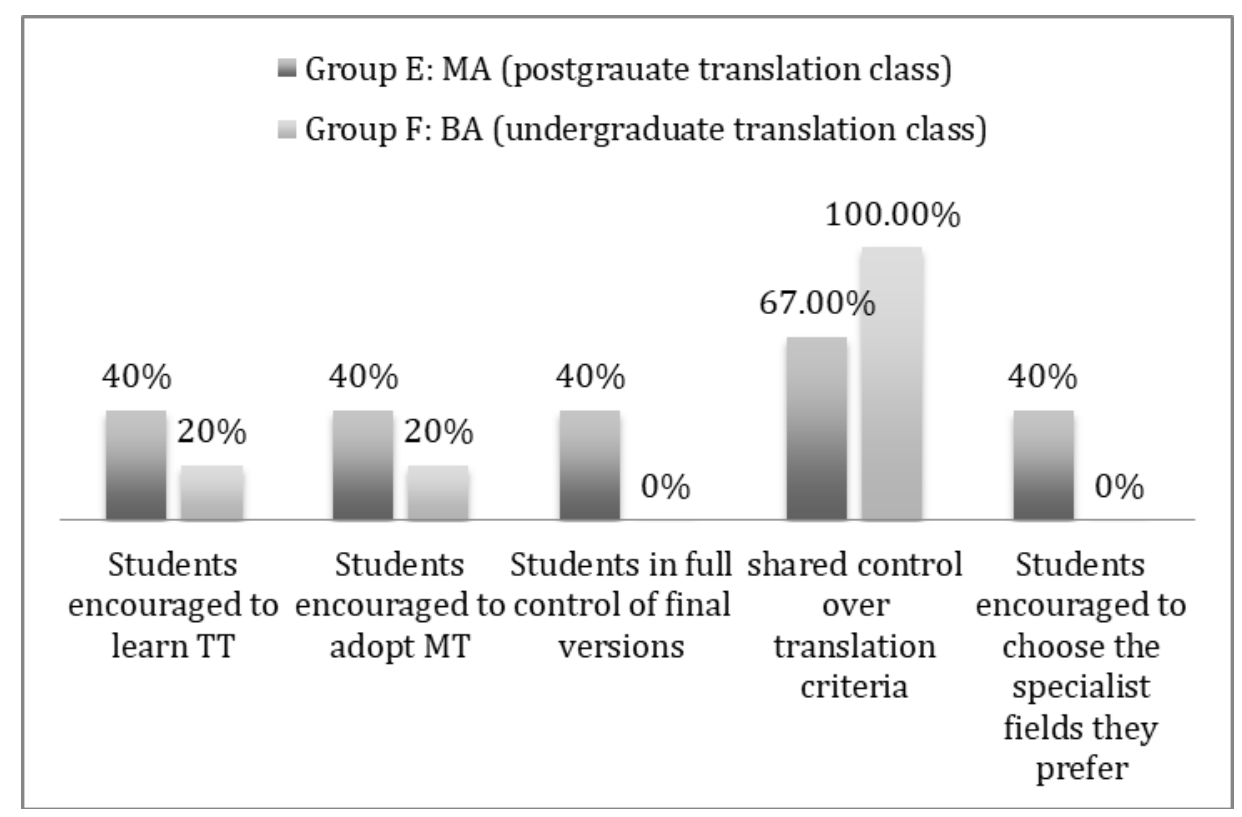

Bar Chart 3. MA \& BA

As is shown in Bar Chart 3, the postgraduates in translation in Group E, compared to the undergraduates in Group F, receive more encouragement to learn translation technologies, adopt machine translation in non-literary translation, decide their final versions completely by themselves and choose the specialist fields they prefer by reading professional literature; moreover, $33 \%$ of teachers do not discuss translation criteria with the postgraduates, believing in their own insight and sound judgment of the translated work. However, in undergraduate level $100 \%$ of teachers discuss translation criteria with students, and none leaves the final versions to the full control of the students. This indicates that in postgraduate translation education students are regarded as more self-reliant and autonomous and thus they are given more choice in goal-setting, more control in translation quality evaluation, and more responsibilities in their own learning process. Nonetheless, undergraduate teachers are noticeably more involved, yes, but also more controlling in the aspects mentioned above to ensure better outcomes, which will be indeed effective to reactive learners among the undergraduates.

\section{Conclusion}

Although the current study is based on a small sample of participants and is limited by the lack of data from students to testify the extent of autonomy, its findings do provide insights into how current translation teachers understand learner autonomy in UK Higher Education in response to the three initial research aims. Firstly, in order to foster autonomous learning in translation, the teachers surveyed provide students with the most choice in translation resources and technologies. They provide less choice in co-deciding translation syllabus, specialized professional goals and teaching materials. Students' holistic understanding of the translation discipline is the teachers' main concern for their participation in those decisions. Secondly, translation students in UK universities seem to share consistent control with their teachers over much of the learning process, from goal-setting, to translation task completion, group collaboration, final version and translation quality criteria decision, to self-evaluation and reflection. Among these aspects, the shared control over the translation product and the translation process, which may assist students to internalize and be more competent translators, is generally acknowledged by the teachers; nevertheless, the importance of encouraging student self-evaluation, peer-evaluation, self reflection, and above all, the writing of translation diaries, seem to be underestimated. Thirdly, to be autonomous learners, students are encouraged to take responsibility for their translation products, collaboration in class, for learning to translate and learning to evaluate and reflect. The more choices provided and the more control shared between students and teachers, the more influence students are believed to have on their learning process, and the more responsibility they are expected to take. This study also shows that teachers see their role as trusted others, either a guide in setting goals, or a coordinator in translation product determination and evaluation, which may be conducive to building a positive teacher-student relation in autonomous learning classroom. Further research would be of great help in promoting teacher awareness of the importance of keeping translation diaries in UK translation education, which can lead students to take more responsibilities in their learning. 


\section{Acknowledgments}

We would like to acknowledge the kind cooperation of all teacher participants, particularly those who offered their invaluable suggestions and detailed explanations. Our sincere gratitude also goes to Professor Anthony Pym, who provided generous help to improve one of our questionnaires and distributed its link to EST (European Society for Translation Studies) list. This paper only adopted and analyzed part of the total data (data from the UK).

\section{References}

Allwright, D. (1990). Autonomy in language pedagogy. In CRILE Working Papers, 6. Center for Research in Education. Lancaster: University of Lancaster, UK.

Benson, P. (1996). Concepts of autonomy in language learning. In R. Pemberton, E. Li, W. Or \& H. Pierson (Eds.), Taking Control: Autonomy in Language Learning (pp. 27-34). Hong Kong: Hong Kong University Press.

Benson, P. (2001). Teaching and Researching Autonomy in Language Learning. Harlow: Pearson Education.

Benson, P. (2010). Measuring autonomy: Should we put our ability to the test? In A. Paran \& L. Sercu (Eds.), Testing the Untestable in Language Education (pp. 77-97). Bristol: Multilingual Matters. https://doi.org/10.21832/9781847692672-007

Benson, P. (2011). Teaching and Researching Autonomy, 2nd edition. Harlow: Pearson Education.

Benson, P., \& Cooker, L. (2013). The Applied Linguistic Individual: Sociocultural Approaches to Identity, Agency and Autonomy. Sheffield, UK: Equinox.

Biau-Gil, J. R., \& Pym, A. (2006). Technology and translation (a pedagogical overview). Translation Technology and its Teaching. In Anthony Pym, Alexander Perestrenko \& Bram Starink (Eds.), Intercultural Studies Group (pp. 5-19). Universitat Rovirai Virgili; Tarragona (Spain).

Chan, V. (2003). Autonomous language learning: the teachers' perspectives. Teaching in Higher Education, 8(1), 33-54. https://doi.org/10.1080/1356251032000052311

Chen, Y. (2010). Trainee translators' reflective learning in small group discussion. In V. Pellatt, K. Kate Griffiths \& S. Wu (Eds.), Teaching and Testing Interpreting and Translating [Text, terminology and translation] (pp. 81-95). Oxford, Bern, Berlin, Bruxelles, Frankfurt am Main, New York, Wien: Peter Lang.

Colina, Sonia. (2003). Translation Teaching: From Research to the Classroom. A Handbook for Teachers. Boston: McGraw-Hill.

Dam, L. (1995). Learner Autonomy 3: From Theory to Classroom Practice. Dublin: Authentik. https://doi.org/10.1016/S0346-251X(97)85684-9

Dickinson, L. (1993). Talking Shop: aspects of autonomous learning. ELT Journa1, 47(4), 330-336. https://doi.org/10.1093/elt/47.4.330

Holec, H. (1981). Autonomy and Foreign Language Learning. Oxford: Pergamon. (First published in 1979, Strasbourg: Council of Europe.)

Hu, W. (2018). Translation Studies in Higher Education Systems: The UK and China. Education, Translation and Global Market Pressures. Singapore: Springer Nature Singapore Pte Ltd. https://doi.org/10.1007/978-981-10-8207-8_1

Johnson, D., \& Johnson, R. (1991). Learning Together and Alone. Englewood Cliffs, N.J.: Prentice Hall.

Kiraly, D. (1995). Pathways to Translation: Pedagogy and Process. Kent: The Kent State University Press. https://doi.org/10.1075/target.9.1.13tir

Kiraly, D. (2000). A Social Constructivist Approach to Translator Education: Empowerment from Theory to Practice. Manchester: St. Jerome Publishing. https://doi.org/10.4324/9781315760186

Kiraly, D. (2003). From instruction to collaborative construction: a passing fad or the promise of a paradigm shift in translation education? In B. Baer \& G. Koby (Eds.), Beyond the Ivory Tower: Rethinking Translation Pedagogy (pp. 3-27). Amsterdam and Philadelphia: John Benjamins. https://doi.org/10.1075/ata.xii.03kir 
Lamb, T. (2008). Learner autonomy and teacher autonomy: synthesising an agenda. In T. Lamb \& H. Reinders (Eds.), Learner and Teacher Autonomy: Concepts, Realities and Responses (pp. 269-284). Amsterdam: John Benjamins. https://doi.org/10.1075/aals.1.21lam

Lewis, T. \& Vialleton, E. (2011). The notions of control and consciousness in learner autonomy and self-regulated learning: a comparison and critique. Innovation in Language learning and Teaching, 5(2), 205-219. https://doi.org/10.1080/17501229.2011.577535

Little, D. (1991). Learner Autonomy 1: Definitions, Issues and Problems. Dublin: Authentik.

Little, D. (1996). Freedom to learn and compulsion to interact: promoting learner autonomy through the use of information systems and information technologies. In R. Pemberton, E. Li, W. Or, \& H. Pierson (Eds.), Taking Control: Autonomy in Language Learning (pp. 203-218). Hong Kong: Hong Kong University Press.

Little, D. (2000). Learner autonomy and human interdependence: some theoretical and practical consequences of a social-interactive view of cognition, learning and language. In B. Sinclair, I. McGrath \& T. Lamb (Eds.), Learner Autonomy, Teacher Autonomy: Future Directions (pp. 15-23). Harlow: Longman/Pearson Education.

Little, D. (2007). Language learner autonomy: some fundamental considerations revisited. Innovation in Language Learning and Teaching, 1(1), 14-29. https://doi.org/10.2167/illt040.0

Littlewood, W. (1999). Defining and developing autonomy in East Asian contexts. Applied Linguistics, 20(1), 71-94. https://doi.org/10.1093/applin/20.1.71

Mellinger, C. D. (2019). Metacognition and self-assessment in specialized translation education: task awareness and metacognitive bundling. Perspectives: Studies in Translatology, 4(27), 604-621. https://doi.org/10.1080/0907676X.2019.1566390

Monzo, E. (2003). Corpus-based Teaching: the Use of Training of Legal Translators. Translation Journal, 7(4). http://translationjournal.net/journal/26edu.htm

Murray, G. (2014). Autonomy in Language learning as a Social Construct. In Garold Murray (Ed.), Social Dimensions of Autonomy in Language Learning (pp. 233-249). London: Palgrave Macmillan. https://doi.org/10.1057/9781137290243.0022

O'Leary, C. (2011). Developing Autonomous Language Learners Within the HE Curriculum: A Postmodern and Social Constructivist Perspective. Unpublished PhD Thesis, available from Sheffield: University of Sheffield Library. Retrieved from https://ethos.bl.uk/OrderDetails.do?uin=uk.bl.ethos.535960

O'Leary, C. (2014). Developing autonomous language learners in HE: a social constructivist perspective. In Garold Murray (Ed.), Social Dimensions of Autonomy in Language Learning (pp. 15-36). London: Palgrave Macmillan. https://doi.org/10.1057/9781137290243_2

Raya, M. J., Lamb, T., \& Vieira, F. (2007). Pedagogy for Autonomy in Language Education in Europe: Towards a Framework for Learner and Teacher Development. Dublin: Authentik.

Scharle, A., \& Szabo, A. (2000). Learner Autonomy: A Guide to Developing Learner Responsibility. Cambridge: Cambridge University Press.

Souto, C., \& Turner, K. (2000). The development of independent students and modern languages learning in non-specialist degree courses: A case study. Journal of Further and Higher Education, 24(3), 385-395. https://doi.org/10.1080/030987700750022307

Vieira, F. (2009). Enhancing pedagogy for autonomy through learning communities: making our dream come true? Innovation in Language Learning and Teaching, 3(3), 269-282. https://doi.org/10.1080/17501220903404525

Vygotsgy, Lev S. (1994). Extracts from thought and language and mind in society. In Barry Stierer \& Janet Maybin (Eds.), Language, Literacy and Learning in Educational Practice (pp. 45-58). Clevedon: Multilingual Matters.

Washbourne, K. (2014). The self-directed learner: intentionality in translator training and education. Perspectives: Studies in Translatology, 22(3), 373-387. https://doi.org/10.1080/0907676x.2013.827225

Williams, M., \& Burden, R. (1997). Psychology for Language Teachers. Cambridge: Cambridge University Press. 
Yashima, T. (2014). Self-regulation and autonomous dependency amongst Japanese learners of English. In Garold Murray (Ed.), Social Dimensions of Autonomy in Language Learning (pp. 60-77). London: Palgrave Macmillan. https://doi.org/10.1057/9781137290243.0010

Yumuk, A. (2002). Letting go of control to the learners: the role of the Internet in promoting a more autonomous view of learning in an academic translation course. Educational Research, 44(2), 141-156. https://doi.org/10.1080/00131880210135278

Zhong, Y. (2008). Teaching translators through self-directed learning. The Interpreter and Translator Trainer, 2(2), 203-220. https://doi.org/10.1080/1750399x.2008.10798774

\section{Copyrights}

Copyright for this article is retained by the author(s), with first publication rights granted to the journal.

This is an open-access article distributed under the terms and conditions of the Creative Commons Attribution license (http://creativecommons.org/licenses/by/4.0/). 